\title{
DRIVERS OF SERVICE INNOVATION: PROPOSAL OF A THEORETICAL MODEL
}

\author{
RICARDO M. LEO ${ }^{1}$ \\ (iD) https://orcid.org/0000-0001-9577-2748 \\ JORGE TELLO-GAMARRA ${ }^{2}$ \\ (iD) https://orcid.org/0000-0002-6344-8422
}

To cite this paper: Leo, R. M., \& Tello-Gamarra, J. (2020). Drivers of service innovation: Proposal of a theoretical model. Revista de Administração Mackenzie, 21(3), 1-27. doi:10.1590/1678-6971/ eRAMR200143

Submission: Aug. 5, 2019. Acceptance: Nov. 21, 2019.

1 Federal University of Rio Grande do Sul (UFRGS), Porto Alegre, RS, Brazil.

2 Federal University of Rio Grande (Furg), Santo Antônio da Patrulha, RS, Brazil.

\section{(c) $\mathrm{BY}$}




\section{ABSTRACT}

Objective: To propose a theoretical model based on nine drivers of service innovation (organizational culture, strategies, research and development, employees, technological trajectory, institutional trajectory, competitors, consumers, and suppliers) in order to comprehend the phenomenon.

Originality/value: Given its recent empowerment and the manufacturing focus it has initially received, service innovation still lacks models that seek to comprehend the phenomenon within an encompassing and particular framework. The originality of this study arises from this issue.

Design/methodology/approach: The method consists of a multiple case study. We used semi-structured interviews with strategic hospital managers and documental research with an analysis of accounting balances, organograms, and other documents. We addressed the cases from a systemic perspective in order to permit comparison within the same structure.

Results: The model permitted us to recognize that the analyzed hospitals were having difficulty innovating, as shown by some characteristics found through the drivers that were proposed by this study. More specifically, the hospitals follow a unidimensional and outdated concept of innovation; that is, they consider innovation in services to be the adoption of technologies from the industry, as shown by Barras (1986). There are also no strategic innovation programs.

\section{KEYWORDS}

Innovation. Services. Drivers. Theoretical model. Hospitals. 


\section{INTRODUCTION}

Initially described by Schumpeter (1911/1997) as a source of economic development for industrial economies, innovation began to encompass services from the moment in which the industry itself increased its mechanization and required technical professionals to support this phenomenon (Bell, 1973; Kindström, Kowalkowski, \& Sandberg, 2013). The ascension of services resulted in a complex and multidimensional scenario of economic activity, enabling the existence of various examples of service innovation, such as services of a simpler nature, including restaurants (Starbucks), streaming services (Netflix) and even those within the industry itself (IBM) (Martin, Gustafsson, \& Choi, 2016).

Many service innovation models have been developed in an attempt to comprehend this reality. Some, however, were based on an industrial viewpoint (Barras, 1986). Others attempted to develop an explanation by examining capabilities (Taghizadeh, Rahman, \& Hossain, 2018; Salunke, Weerawardena, \& McColl-Kennedy, 2019) or even through the lean concept (Ojasalo \& Ojasalo, 2018). This scenario shows that, due to their recent empowerment and fuzzy (poorly articulated and formalized) character, services still do not possess consolidated models that attempt to comprehend innovation within an encompassing framework (Gallouj \& Weinstein, 1997; Thanasopon, Papadopoulos, \& Vidgen, 2016).

Despite this, the relationship between service innovation and economic development suggests that there are variables to be managed by the firms, and, thus, if there is a need for management, there is a need to determine what to manage (Abouzeedan, Klofsten, \& Hedner, 2013). This suggestion prompted the exploration of organizational and environmental variables, which are herein denominated "drivers", associated with the development of service innovation (Naranjo-Gil, 2009). These studies consider service innovation as propelled by the environmental specificities of where the firm is located, as well as its organizational variables, which create different panoramas that must be understood (Madrid-Guijarro, Garcia, \& Auken, 2009).

Although these studies are advancing, there is still much to be done to overcome recurrent difficulties. Aside from the need to identify these drivers (Prajogo \& McDermott, 2014; Durst, Mention, \& Poutanen, 2015), there is also a need to overcome the manufacturing lens that service innovation researchers initially used to study the phenomenon (Gallouj, 2002). In this sense, understanding service innovation requires identifying and analyzing 
which drivers are a part of the phenomenon, so that the gaps found in the literature can be filled, consolidating service innovation models and understanding economic development in economies where services are central in the economy (Naranjo-Gil, 2009).

Since the literature in this field of study still does not possess a solid scientific foundation and needs studies that advance its consolidation (Daniel, Lina, \& Dambros, 2017; Witell et al., 2017), the present article proposes a theoretical model that groups the service innovation drivers. Such a model seeks to present an encompassing vision of the firm; that is, due to the exploratory nature, it will seek to analyze the particular specificities of service firms.

The article is structured as follows: after this introductory section, there is a literature review that maps the scenario of service innovation and presents the drivers that serve as a base for the proposition of the model. The proposed model is applied through a multiple case study conducted in four hospitals located in the Brazilian state of Rio Grande do Sul. We present a detailed description of the results. Finally, we present the conclusions, limitations, and suggestions resulting from this study.

\section{THEORETICAL REFERENCES}

The "Service innovation" section below describes the background to this study. We then discuss the drivers of service innovation, which will be used in the proposed theoretical model and are herein known as "Drivers of service innovation".

\subsection{Service innovation}

Discussing service innovation is not a simple task. Initially, services were defined in economic theory as non-productive jobs (Smith, 1983). At the time, treating services as non-productive jobs did not matter, as economies were sustained by industry and by agriculture. Years later, economic logic was inverted, although industrial echoes remained, skewing the manner in which the service economy was seen (Barras, 1986; Gallouj, \& Weinstein, 1997).

Such biases may be seen in the first of four approaches - assimilation - in which service innovation was a result of the adoption of technologies originating in the manufacturing industry (Barras, 1986). As a consequence, inno- 
vation would not be the analysis of a process, but the diffusion of technological innovation in the service industry, ignoring any other forms of innovation, such as those stemming from the relationship between service users and suppliers.

Upon noticing this disregard and already possessing a notion that service innovation was already going beyond the mere adoption of technology, researchers began to base their work upon the supposition that services possess specificities beyond said technological adoption - demarcation - and directed their focus to the user-suppliers relationship, in order to establish a counterpoint (Ordanini \& Parasuraman, 2011). Upon focusing on the distinctive characteristics of the services, however, the approach loses its generality because it falls into the same trap as the technological approach.

Later on, the inversion approach made its appearance. This approach sees services as a source of innovation for the entire economy and maintains that innovation stems from intensive-knowledge services. This would happen through the suppliers' knowledge use, emphasizing their role as intensiveknowledge service providers, as it would be the case for consultancy, engineering, and research service firms.

Finally, there is the integration approach, which proposes a reconciliation between the industry and services in a single framework. Gallouj and Weinstein (1997) developed this approach by applying the Lancasterian model of goods and services, defining them as a spectrum of vectors. Changes in these vectors would be the sources of innovation.

The theoretical construction of this subject has always been tilted to one point of view, whether focusing on human relations or on the technological aspects. This belated search for an integrated vision reinforces the proposal of broad studies that include in their analysis unit the whole of the subject's complexity, as it is a poorly articulated and formalized process. With this in mind, we searched the literature for background to propose an encompassing and integrated theoretical framework that would provide elements to better comprehend service innovation, and that is capable of capturing its particularities.

\subsection{Drivers of service innovation}

Service innovation consists of obtaining superior performance through the proposition of value, thanks to a group of preexisting resources or through the creation of new ones (Damanpour, 1991; Skålén, Gummerus, Khoskull, \& Magnusson, 2015). In order to reach this objective, the firm 
must consider the forces that mold this group of resources, leading a service firm to innovate and, consequently, to achieve superior performance (Hauknes, 1998; Chen, Tsou, \& Huang, 2009).

Service innovation thus leads to the domination of the diverse group of drivers that are a part of the phenomenon (Kindström et al., 2013) and, according to the SII4S reports (Services Innovation, Innovation for Services), these drivers can be grouped into internal or external. After an extensive literature review, this article proposes a model to understand service innovation. This model is based on nine drivers, four of which are internal and five, external, which guide the firm towards service innovation.

The four internal drivers include organizational culture, strategies, human capital, and research and development (R\&D). Organizational culture is the system of values, beliefs and hidden presuppositions that the members of an organization have in common (Miron, Erez, \& Naveh, 2004). A firm's strategy establishes the framework in which the innovations are developed (Sundbo, 2006). Human capital involves a firm's collaborators and their abilities, which are also important in the service sector because the innovation process employs workers who are in contact with consumers (Pires, Sarkar, \& Carvalho, 2008). The literature also maintains that research and development (R\&D) are sources of innovation for firms, because they help create knowledge that previously did not exist in the company (Community Innovation Survey [CIS], 2012).

The external drivers involve the trajectories and the actors. A technological trajectory consists of a group of possible technological directions whose exterior limits are defined by the nature of the paradigm itself, through trade-offs with the relevant technological variables (Dosi, 1982). In this sense, the employment of technology through time guides the firm (or not) towards innovation (Nelson \& Winter, 1982; Hauknes, 1998; Pilat, 2000; Pires et al., 2008). The institutional trajectory describes the tendency towards the evolution of regulations, and political and public institutions, as well as the development of social rules and conventions that govern society (Berger \& Luckmann, 1978; Dosi, 1982).

The actors are economic agents that influence the sale of a certain firm's services and, thus, its innovative activities as well. Establishing and maintaining good relations with partners tends to improve innovative performance (Hsueh, Lin, \& Li, 2010). There are three actors involved in this second variable of the external environment: competitors, consumers, and suppliers. Competitors are fundamental because competition stimulates innovation. The consumers are the firm's final focus when providing its 
services, as well as acting as a source of knowledge for service improvements. Finally, the firm depends on the supplies that will be used in the service provision, so the suppliers appear as collaborators within the service provision process and, consequently, in innovation (Hauknes, 1998; Leiponen, 2006).

As the objective of this study is to propose a theoretical model, these drivers are complemented with three control variables that are recurrent in the literature: location, firm age and size. The location has to do with the fact that firms depend on external agents (Pilat, 2000). Firm age may have an effect on service innovation, as it is related to organizational learning and performance (Bessant $\&$ Tidd, 2009). Similarly, a firm's size may have effects on innovation, because it is related to a firm's capability to adapt to environmental changes, as well as to resources access (Pires et al., 2008; Bessant \& Tidd, 2009).

Finally, to speak of innovation is to refer to superior performance (Schumpeter, 1911). Empirical studies point out that the relationship between innovation and performance is a positive one (Damanpour, 1991). It is, therefore, not appropriate to evaluate only the drivers; financial and nonfinancial performance should also be evaluated.

Financial performance is characterized by how companies use their assets to generate revenue (Chen et al., 2009), that is, they reflect the fulfillment of the firm's economic objectives. Non-financial performance is characterized as a long-term operational objective that aims to increase customer fidelity as a part of its objectives (Kaplan \& Norton, 1996). Upon analyzing the literature, we thus proposed the theoretical model shown in Figure 2.2.1.

It is important to point out that the internal and external blocks interact from the very moment a firm decides to improve its internal drivers (Marcus \& Geffen, 1998). This happens through the identification of its competitors' practices and its better relationship with its consumers and suppliers, as well as through the acquisition of new technologies to apply to the productive process. It is also important to emphasize that the firm's age directly affects organizational learning, location affects the actors and the firm size affects access to resources, which is why they are control variables.

In order to sustain the proposed model and describe the following cases, we searched for indicators in the literature that support each one of the proposed drivers. Twenty-five indicators were related to the drivers, aside from the three control variables. Figure 2.2.2 shows these indicators, as well as their respective distribution within the drivers. 


\section{(Figure 2.2.1)}

\section{SERVICE INNOVATION DRIVERS}

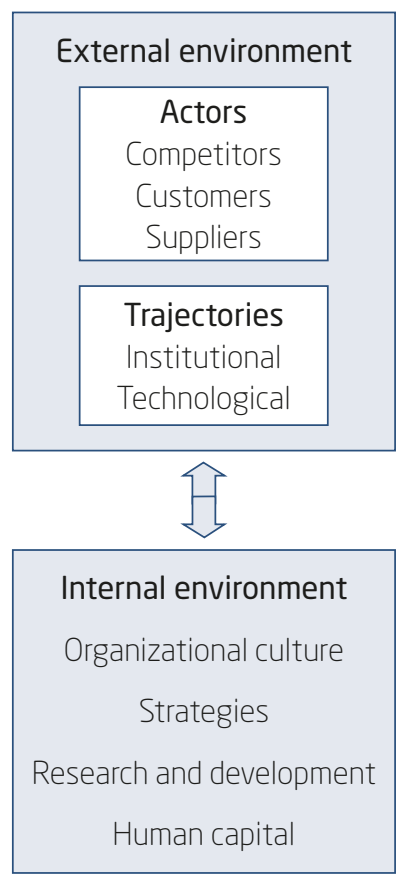

Source: Elaborated by the authors.

(Figure 2.2.2)

DRIVERS OF SERVICE INNOVATION

\begin{tabular}{lll}
\hline \multicolumn{1}{c}{ Internal drivers } & \multicolumn{1}{c}{ Indicators } & \multicolumn{1}{c}{ References } \\
\hline & Stimulating creative thinking & Shattow (1996) \\
\cline { 2 - 3 } $\begin{array}{l}\text { Organizational } \\
\text { culture }\end{array}$ & $\begin{array}{l}\text { Freedom and autonomy for human } \\
\text { capital }\end{array}$ & McLean (2005) \\
\cline { 2 - 3 } & Risk acceptance & Claver, Llopis, Garcia, and Molina \\
& & (1998) \\
\hline & Innovation as a strategic part of & Toivonen and Tuominen (2009), \\
the firm & Bessant and Tidd (2009) and Radaelli, \\
& & Currie, Frattini, and Lettieri (2017). \\
\cline { 2 - 3 } Strategies & Mechanisms to analyze technological & Bessant and Tidd (2009) \\
& and market developments & \\
\hline
\end{tabular}




\section{(Figure 2.2.2 (continuation)) \\ DRIVERS OF SERVICE INNOVATION}

\begin{tabular}{|c|c|c|}
\hline Internal drivers & Indicators & References \\
\hline Strategies & $\begin{array}{l}\text { Raising awareness among employees } \\
\text { about innovation strategies }\end{array}$ & Bessant and Tidd (2009) \\
\hline \multirow{3}{*}{ Employees } & $\begin{array}{l}\text { Training for innovative activities and } \\
\text { for the use of new technology }\end{array}$ & $\begin{array}{l}\text { Camisón and Monfort-Mir (2012) and } \\
\text { CIS (2012) }\end{array}$ \\
\hline & $\begin{array}{l}\text { Rewards for the suggestion of ideas } \\
\text { to improve services and processes }\end{array}$ & $\begin{array}{l}\text { Bessant and Tidd (2009) and Ostrom } \\
\text { et al. (2010) }\end{array}$ \\
\hline & $\begin{array}{l}\text { Degree of qualification and how } \\
\text { selection and recruiting are conducted }\end{array}$ & $\begin{array}{l}\text { CIS (2012) and Camisón and Monfort- } \\
\text { Mir (2012) }\end{array}$ \\
\hline \multirow{3}{*}{$\begin{array}{l}\text { Research and } \\
\text { development }\end{array}$} & $\begin{array}{l}\text { Existence of R\&D centers and } \\
\text { their relationships with research } \\
\text { institutions and/or hiring of } \\
\text { external R\&D }\end{array}$ & $\begin{array}{l}\text { Yam, Guan, Pun, and Tang (2004) and } \\
\text { CIS (2012) }\end{array}$ \\
\hline & Expenses with R\&D & Camisón and Monfort-Mir (2012) \\
\hline & $\begin{array}{l}\text { R\&D development for creating new } \\
\text { knowledge }\end{array}$ & $\operatorname{CIS}(2012)$ \\
\hline External drivers & Indicators & References \\
\hline \multirow{2}{*}{$\begin{array}{l}\text { Technological } \\
\text { trajectory }\end{array}$} & $\begin{array}{l}\text { Employment of technologies over } \\
\text { time that are compatible or superior } \\
\text { to those used by the competition }\end{array}$ & $\begin{array}{l}\text { CIS (2012) and Camisón and Monfort- } \\
\text { Mir (2012) }\end{array}$ \\
\hline & $\begin{array}{l}\text { Technology management and } \\
\text { technical abilities }\end{array}$ & Bharadwaj (2000) \\
\hline \multirow{2}{*}{$\begin{array}{l}\text { Institutional } \\
\text { trajectory }\end{array}$} & $\begin{array}{l}\text { Incentives and barriers imposed by } \\
\text { the state throughout the years }\end{array}$ & $\begin{array}{l}\text { Dosi (1982) and Camisón and } \\
\text { Monfort-Mir (2012), and CIS (2012) }\end{array}$ \\
\hline & $\begin{array}{l}\text { Social taboos, punishments, customs, } \\
\text { traditions, and codes of conduct }\end{array}$ & Berger and Luckmann (1978) \\
\hline \multirow{2}{*}{ Competitors } & Sharing of experiences & $\begin{array}{l}\text { CIS (2012) and Bessant and Tidd } \\
\text { (2009) }\end{array}$ \\
\hline & $\begin{array}{l}\text { Systematic comparison of services } \\
\text { and processes }\end{array}$ & Bessant and Tidd (2009) \\
\hline Consumers & Comprehending consumer needs & $\begin{array}{l}\text { Bessant and Tidd (2009) and Pinto, } \\
\text { Dell'Era, Verganti and Bellini (2017) }\end{array}$ \\
\hline
\end{tabular}


(Figure 2.2.2 (conclusion))

DRIVERS OF SERVICE INNOVATION

\begin{tabular}{|c|c|c|}
\hline External drivers & Indicators & References \\
\hline Consumers & $\begin{array}{l}\text { Definition of the consumer role and } \\
\text { the development of methods to } \\
\text { encourage them }\end{array}$ & $\begin{array}{l}\text { Ostrom et al. (2010) and Larivière } \\
\text { et al. (2017) }\end{array}$ \\
\hline \multirow[t]{2}{*}{ Suppliers } & $\begin{array}{l}\text { Maintaining a good relationship with } \\
\text { suppliers }\end{array}$ & Bessant and Tidd (2009) \\
\hline & Evaluating the suppliers & Winter and Lasch (2016) \\
\hline Control variables & Indicators & References \\
\hline Size & $\begin{array}{l}\text { Approximate revenue from the last } \\
\text { financial year }\end{array}$ & $\begin{array}{l}\text { Bessant and Tidd (2009), CIS (2012), } \\
\text { and Pires et al. (2008) }\end{array}$ \\
\hline Age & Firm age & Bessant and Tidd (2009) \\
\hline Location & Where it is located & $\begin{array}{l}\text { Bessant and Tidd (2009) and CIS } \\
\text { (2012) }\end{array}$ \\
\hline Performance & Indicators & References \\
\hline \multirow{2}{*}{$\begin{array}{l}\text { Financial } \\
\text { performance }\end{array}$} & Sales variation & Morgan, Vorhies, and Mason (2009) \\
\hline & Profits variation & Calantone, Cavusgil, and Zhao (2002) \\
\hline $\begin{array}{l}\text { Non-financial } \\
\text { performance }\end{array}$ & Variation of new customer acquisition & Kaplan and Norton (1996) \\
\hline
\end{tabular}

Source: Elaborated by the authors.

The present model aims to fill in the gap of inadequate indicator usage when dealing with service innovation, as well as to remedy the lack of an encompassing theoretical framework that provides tools that advance the understanding of this reality, according to its indicators.

\section{METHOD}

\subsection{Research approach}

We used a multiple case study (Yin, 2005; Kindström et al., 2013), given the relative lack of a consolidated paradigm in the topic. This approach is justified by the need to understand complex social phenomena, contributing to the knowledge about the subject and deepening the theory (Yin, 2005). 


\subsection{Sample, data collection and analysis}

Hospitals were chosen due to the value placed on this type of service in society and since they require constant improvement, given that they deal directly with life. With this in mind, we first mapped the hospitals in the State of Rio Grande do Sul and then contacted them to verify their availability. Since there were large percentages of abstention, the sampling was conducted by convenience. In this type of sampling, the elements are deliberately chosen with the understanding that they, somehow, represent the sample universe (Malhotra, 2012).

We applied a questionnaire in the form of semi-structured interviews. The interviews were conducted in February 2017, with the strategic managers (administrative manager, controllership director, medical provider, and manager) of four hospitals in the State of Rio Grande do Sul, Brazil. Each interview lasted for approximately one and a half hours. When the interviews were over, the recordings were transcribed and stored for analysis. Documental research was also used, based on accounting balances, organograms, missions, visions, values, and other information. Figure 3.2.1 shows the research protocol that was used.

Finally, we took a systemic perspective on the case study analysis. This technique permits the comparison of cases within the same structure (Yin, 2005). It is important to point out that the case analyses lasted from May 2017 until May 2019.

(Figure 3.2.1)

RESEARCH PROTOCOL

\begin{tabular}{cl}
\hline \multirow{2}{*}{ Objective } & Proposing a theoretical model to describe service innovation. \\
\hline \multirow{2}{*}{ Design } & Multiple cases. \\
\cline { 2 - 2 } & Hospitals were chosen due to the industrial viewpoints to analyze the topic. \\
\cline { 2 - 2 } Case selection & Survey of drivers that direct service innovation. \\
\hline Procedures & $\begin{array}{l}\text { Approval of Research Ethics Committee and appropriate procedures, according } \\
\text { to each hospital. }\end{array}$ \\
\hline \multirow{2}{*}{ Data collection } & $\begin{array}{l}\text { Literature review to theoretically reference the proposed model and its } \\
\text { indicators. }\end{array}$ \\
\hline
\end{tabular}


(Figure 3.2.1 (conclusion))

RESEARCH PROTOCOL

\begin{tabular}{cl}
\hline \multirow{2}{*}{ Data collection } & \multicolumn{1}{c}{$\begin{array}{l}\text { Contact was made to verify the participation. If this was possible, procedures } \\
\text { were begun in each hospital. }\end{array}$} \\
\cline { 2 - 2 } Analysis & $\begin{array}{l}\text { Demi-structured interviews with strategic managers in the hospitals. } \\
\text { (Yin, 2005). }\end{array}$ \\
\hline
\end{tabular}

Source: Adapted from Yin (2005).

\section{RESULTS}

The results are discussed in individual sections for control variables, internal drivers, external drivers, and, finally, performance, in that order. At the end of each subsection, a figure synthesizes the results of each driver.

\subsection{Control variables}

The hospitals had revenues that ranged from 30 to 85 million Brazilian Reais, were aged between 3 and 155 years old, and are located in different regions of the State of Rio Grande do Sul: the central region, Campanha region, south-central region and the metropolitan area of Porto Alegre. Figure 4.1.1 synthesizes the control variables from the studied cases.

\section{(Figure 4.1.1)}

SYNTHESIS OF THE CONTROL VARIABLES

\begin{tabular}{llcccc}
\hline Variables & \multicolumn{1}{c}{ Indicators } & Case 1 & Case 2 & Case 3 & Case 4 \\
\hline \multirow{2}{*}{ Size } & $\begin{array}{l}\text { Approximate revenue from the } \\
\text { last financial year (in Brazilian } \\
\text { reais) }\end{array}$ & 85 million & 30 million & 35 million & 60 million \\
\hline Age & Age (in years) & 47 & 155 & 41 & 3 \\
\hline Location & Where it is located & $\begin{array}{c}\text { Central } \\
\text { region }\end{array}$ & $\begin{array}{c}\text { Campaign } \\
\text { region }\end{array}$ & $\begin{array}{c}\text { South-central } \\
\text { region }\end{array}$ & $\begin{array}{c}\text { Metropolitan } \\
\text { region }\end{array}$ \\
\hline
\end{tabular}

Source: Elaborated by the authors. 
These variables were neutralized by setting them as control variables. Obviously, in multiple case studies, the variables assume another character, but since this paper's objective is to propose a model for later quantification, the variables assume the condition of control variables.

\subsection{Internal drivers}

The first internal driver was organizational culture, based on value systems, beliefs and hidden presuppositions that are shared by the members of an organization (Miron et al., 2004) in order to promote creative thinking (Shattow, 1996), freedom/autonomy (McLean, 2005) and risk acceptance (Claver et al., 1998). The analyzed hospitals showed structures that were slanted towards creative thinking, freedom/autonomy, and risk acceptance. This culture is supported by mechanisms, such as the management of competences, operative plans, and the freedom to suggest practices that may generate value. This can be seen in three of the four analyzed cases. The discordant case demonstrated a stiff structure that does little to promote the freedom and creativity of its personnel.

The hospital has a stiff structure. Historically, it is a home, a hotel, where there is a quest for health. Over the years, especially in public hospitals, the hospitality aspect was shunted to the side. Currently, we are attempting to make a difference with our hospitality, but it is very early (Administrative Manager - case 1).

Indicators such as the manager's perception of innovation, the establishment of strategies to develop it (Toivonen \& Tuominen, 2009; Bessant \& Tidd, 2009), the implementation of mechanisms to analyze technological and market development (Bessant \& Tidd, 2009), and the awareness of the employees about the firm's innovation strategies (Bessant \& Tidd, 2009) are relevant. The data suggests that there is no strategic program developed by the hospitals in order to reach innovation.

However, there are programs for the acquisition of new technologies based on pricing, which means that due to financial issues, the hospitals attempt to find (benchmarking and bidding) technologies that fit into their financial reality. Hospitals attempt to make their employees aware of their financial situation, through meetings or routine activities. The following dialogue shows something of the strategic reality of the hospitals analyzed here: "This process is almost non-existent. The hospital does not have a clear strategy. Honestly, this is still not something that we can say we have at work" (Administrative Manager - case 1). 
The "employees" driver consisted of training given to the collaborators for innovative activities or for using new technology (Camisón \& MonfortMir, 2012; CIS, 2012), for suggestions made to improve services or processes, the rewards given for this activity (Bessant \& Tidd, 2009; Ostrom et al., 2010), the level of qualification of the employees, and how selections are made (CIS, 2012; Camisón \& Monfort-Mir, 2012). In general, all hospitals had training that was more skewed towards technology, to the detriment of other intangible aspects of their services, normally using their suppliers to provide this training or tools, such as Plan-Do-Check-Act (PDCA). There were sometimes specific meetings for brainstorming and cases in which efforts were made so that this process occurred organically. Finally, two cases analyzed here had employees with high school and college degrees, and the others, thanks to the hospitals being located near universities, had collaborators at all academic levels, from elementary school to Ph.D. The selection process for these employees involved entrance exams and processes that are specific for each hospital.

The R\&D internal driver was based the existence of $R \& D$ centers and their relations to research institutions and/or the hiring of external R\&D (Yam et al., 2004; CIS, 2012), as well as expenses incurred for these activities (Camisón \& Monfort-Mir, 2012) and the development of R\&D activities to create new knowledge (CIS, 2012). Two of the hospitals had institutionalized research centers, where researches were developed to benefit the hospital and the scientific community, as well as to receive students through partnerships with universities. All of the hospitals developed specific projects to solve internal issues. Examples of this are the projects to reduce energy consumption, the implementation of quality control programs, audits, and sustainability projects. Figure 4.2.1 synthesizes the internal drivers.

\section{(Figure 4.2.1)}

SYNTHESIS OF THE INTERNAL DRIVERS

\begin{tabular}{|c|c|c|c|c|c|}
\hline Drivers & Indicators & Case 1 & Case 2 & Case 3 & Case 4 \\
\hline $\begin{array}{l}\text { Organizational } \\
\text { culture }\end{array}$ & $\begin{array}{l}\text { Encouraging } \\
\text { personnel to think } \\
\text { creatively. }\end{array}$ & $\begin{array}{l}\text { Stiff structure } \\
\text { with little } \\
\text { creativity }\end{array}$ & $\begin{array}{l}\text { Suggestions } \\
\text { allowed at any } \\
\text { time, which } \\
\text { helps creativity. }\end{array}$ & $\begin{array}{l}\text { Management } \\
\text { through } \\
\text { competences } \\
\text { to develop } \\
\text { abilities } \\
\text { creatively. }\end{array}$ & $\begin{array}{l}\text { Projects to } \\
\text { highlight the } \\
\text { employees. }\end{array}$ \\
\hline
\end{tabular}




\section{(Figure 4.2.1 (continuation))}

SYNTHESIS OF THE INTERNAL DRIVERS

\begin{tabular}{|c|c|c|c|c|c|}
\hline Drivers & Indicators & Case 1 & Case 2 & Case 3 & Case 4 \\
\hline \multirow[b]{2}{*}{$\begin{array}{l}\text { Organizational } \\
\text { culture }\end{array}$} & $\begin{array}{l}\text { Environment of } \\
\text { freedom and } \\
\text { autonomy for the } \\
\text { human capital }\end{array}$ & $\begin{array}{l}\text { Open for } \\
\text { people to } \\
\text { develop } \\
\text { freely. }\end{array}$ & $\begin{array}{l}\text { Freedom to } \\
\text { discuss the } \\
\text { process at any } \\
\text { time. }\end{array}$ & $\begin{array}{l}\text { Delegates } \\
\text { autonomy } \\
\text { responsibly. }\end{array}$ & $\begin{array}{l}\text { Freedom to } \\
\text { bring up ideas } \\
\text { that generate } \\
\text { value. }\end{array}$ \\
\hline & $\begin{array}{l}\text { Personnel used to } \\
\text { risk acceptance }\end{array}$ & $\begin{array}{l}\text { Aware of } \\
\text { activity- } \\
\text { inherent risks. }\end{array}$ & $\begin{array}{l}\text { Risks are } \\
\text { comprehended } \\
\text { through a } \\
\text { specific } \\
\text { decision-making } \\
\text { apparatus. }\end{array}$ & $\begin{array}{l}\text { Operative } \\
\text { plans that } \\
\text { define the } \\
\text { collaborator's } \\
\text { capacities. }\end{array}$ & $\begin{array}{l}\text { Risk } \\
\text { acceptance is } \\
\text { a characteristic } \\
\text { that is a part } \\
\text { of the } \\
\text { profession. }\end{array}$ \\
\hline \multirow{3}{*}{ Strategies } & $\begin{array}{l}\text { Perception of } \\
\text { innovation as a } \\
\text { strategic factor }\end{array}$ & $\begin{array}{l}\text { Nonexistent } \\
\text { strategic } \\
\text { program. }\end{array}$ & $\begin{array}{l}\text { Adoption of } \\
\text { new } \\
\text { technologies. }\end{array}$ & $\begin{array}{l}\text { Adoption of } \\
\text { new } \\
\text { technologies. }\end{array}$ & $\begin{array}{l}\text { Innovation as a } \\
\text { strategic } \\
\text { variable. }\end{array}$ \\
\hline & $\begin{array}{l}\text { Mechanisms to } \\
\text { analyze market } \\
\text { and technological } \\
\text { developments }\end{array}$ & Cost/benefit. & Cost/benefit. & $\begin{array}{l}\text { Specific } \\
\text { courses. }\end{array}$ & $\begin{array}{l}\text { Benchmarking } \\
\text { and syndical } \\
\text { participation. }\end{array}$ \\
\hline & $\begin{array}{l}\text { Raising employee } \\
\text { awareness about } \\
\text { innovation } \\
\text { strategies }\end{array}$ & $\begin{array}{l}\text { Nonexistent } \\
\text { innovation } \\
\text { strategies. }\end{array}$ & $\begin{array}{l}\text { From the } \\
\text { selection } \\
\text { process } \\
\text { onwards. }\end{array}$ & $\begin{array}{l}\text { Periodic } \\
\text { meetings to } \\
\text { clarify the } \\
\text { strategies. }\end{array}$ & $\begin{array}{l}\text { Periodic } \\
\text { meetings to } \\
\text { clarify the } \\
\text { strategies. }\end{array}$ \\
\hline \multirow{3}{*}{ Employees } & $\begin{array}{l}\text { Training for } \\
\text { innovative } \\
\text { activities and the } \\
\text { use of new } \\
\text { technologies }\end{array}$ & $\begin{array}{l}\text { Training for } \\
\text { new } \\
\text { technology. }\end{array}$ & $\begin{array}{l}\text { Training for new } \\
\text { technology. }\end{array}$ & $\begin{array}{l}\text { Training for } \\
\text { new } \\
\text { technology. }\end{array}$ & PDCA tool. \\
\hline & $\begin{array}{l}\text { Employees make } \\
\text { suggestions for } \\
\text { better services } \\
\text { and processes and } \\
\text { are rewarded }\end{array}$ & $\begin{array}{l}\text { Periodic } \\
\text { meetings. } \\
\text { No rewards. }\end{array}$ & $\begin{array}{l}\text { Organically. } \\
\text { No rewards. }\end{array}$ & $\begin{array}{l}\text { Periodic } \\
\text { meetings. } \\
\text { No rewards. }\end{array}$ & $\begin{array}{l}\text { Organically. } \\
\text { Rewards. }\end{array}$ \\
\hline & $\begin{array}{l}\text { Degree of } \\
\text { qualification and } \\
\text { how selection and } \\
\text { recruiting are } \\
\text { conducted }\end{array}$ & $\begin{array}{l}\text { From high } \\
\text { school to Ph.D. } \\
\text { Selection } \\
\text { through public } \\
\text { entrance } \\
\text { exam. }\end{array}$ & $\begin{array}{l}\text { From high } \\
\text { school and } \\
\text { college. } \\
\text { Selection } \\
\text { conducted } \\
\text { through a } \\
\text { profile matrix. }\end{array}$ & $\begin{array}{l}\text { From high } \\
\text { school and } \\
\text { college. } \\
\text { Selection } \\
\text { conducted } \\
\text { by the } \\
\text { psychologist } \\
\text { and directors. }\end{array}$ & $\begin{array}{l}\text { From high } \\
\text { school to Ph.D. } \\
\text { Recruiting and } \\
\text { selection } \\
\text { through a } \\
\text { specific } \\
\text { process. }\end{array}$ \\
\hline
\end{tabular}


(Figure 4.2.1 (conclusion))

SYNTHESIS OF THE INTERNAL DRIVERS

\begin{tabular}{|c|c|c|c|c|c|}
\hline Drivers & Indicators & Case 1 & Case 2 & Case 3 & Case 4 \\
\hline \multirow{3}{*}{$R \& D$} & $\begin{array}{l}\text { Existence of R\&D } \\
\text { centers, relations } \\
\text { with research } \\
\text { institutions, and/ } \\
\text { or hiring of } \\
\text { external R\&D }\end{array}$ & $\begin{array}{l}\text { Yes; } \\
\text { partnerships } \\
\text { with the } \\
\text { private } \\
\text { initiative. }\end{array}$ & Nonexistent. & Nonexistent. & $\begin{array}{l}\text { Epidemiology } \\
\text { nucleus. } \\
\text { They have a } \\
\text { relationship } \\
\text { with } \\
\text { universities. }\end{array}$ \\
\hline & Expenses & $\begin{array}{l}2 \% \text { of total } \\
\text { revenues. }\end{array}$ & None. & None. & $\begin{array}{l}\text { Between } 1 \% \\
\text { and } 2 \% \text { of } \\
\text { monthly } \\
\text { revenue. }\end{array}$ \\
\hline & $\begin{array}{l}\text { Developing R\&D } \\
\text { activities to create } \\
\text { new knowledge } \\
\text { that solves } \\
\text { problems }\end{array}$ & $\begin{array}{l}\text { Reduction of } \\
\text { energy } \\
\text { consumption. }\end{array}$ & $\begin{array}{l}\text { Audits and } \\
\text { strategic } \\
\text { planning. }\end{array}$ & $\begin{array}{l}\text { Projects for } \\
\text { there to be } \\
\text { full-time } \\
\text { doctors. }\end{array}$ & $\begin{array}{l}\text { Sustainability } \\
\text { projects. }\end{array}$ \\
\hline
\end{tabular}

Source: Elaborated by the authors.

The internal drivers show an organizational culture of relative freedom and the stimulation of creativity, as well as risk awareness. However, the hospitals do not possess specific innovation strategies, which, as a consequence, stops the employees from having knowledge of such strategies. Finally, some hospitals do not have institutionalized R\&D centers.

\subsection{External drivers}

The technological trajectory focused on long term technology employment, with said technologies being superior or compatible with those used by the competition (Camisón \& Monfort-Mir, 2012; CIS, 2012) and the technical and management abilities of these technologies (Bharadwaj, 2000). This trajectory is marked by the acquisition of new technologies; that is, all of the hospitals emphasized that their pathways contained relatively low employment of technology until the 2000s when they began to acquire their specific technologies. The comparison of these technologies with those used by the competition and technical management took place through benchmarking, hospital network participation, and other activities. This can be seen in the following dialogue. 
In October of 2012, we were able to achieve integration through the system, which made the hospital start investing in technology in all of its fields. Nowadays, all of our medical area is digital, patient charts are $100 \%$ electronic, etc. This brought us gains in quality and solutions (Director of controllership - case 3).

The second external driver, institutional trajectory, is present through the incentives and barriers imposed by the public sector throughout the years (Dosi, 1982; Camisón \& Monfort-Mir, 2012; CIS, 2012), aside from societal taboos, punishments, customs, traditions and conduct codes (Berger \& Luckmann, 1978). With this in mind, all of the cases stated that institutional changes imposed by the public sector had great impacts on them, whether due to constitutional changes, contracts, or other factors. The hospitals consider societal aspects according to geography, climate, local festivities and taboos that are linked to risk classifications.

Also, having competitors in their partner network with whom they can share experiences (Bessant \& Tidd, 2009; CIS, 2012) and systematically compare services and processes (Bessant \& Tidd, 2009) are important factors for innovation. All the hospitals share experiences and compare services and processes through the partners network, whether through networks mediated by the Brazilian Company of Hospital Services, the Federation of Santa Casa and Beneficent Hospitals or even within hospitals that are a part of the same organization. However, even performing these activities, the four cases analyzed claim that they do not have competitors.

The fourth external driver, the consumers, also plays an important role. Possessing a thorough understanding of customer needs (Bessant \& Tidd, 2009) and developing methods to stimulate them to participate in the process (Ostrom et al., 2010) are related to innovation. All of the cases shown here have activities that aim to understand the needs of their consumers, such as socioeconomic surveys, satisfaction surveys, and other such tools. In order to stimulate consumers to participate in the process, there is also special training to improve the relationship between employees and patients.

Finally, suppliers, the last external driver, are supported by indicators, such as maintaining good relations (mutual benefit) with suppliers (Bessant $\&$ Tidd, 2009), and evaluating them (Winter \& Lasch, 2016). The hospitals deal with their suppliers through variable pricing. Since they have economic difficulties, their relationships with their suppliers are guided by the lowest price. This can be found through bidding, invitations, quotations, and other forms of relationship. Digital platforms and specific sectors also seek to 


\section{evaluate the suppliers that do business with the hospitals. Figure 4.3.1 synthesizes the results concerning external drivers.}

(Figure 4.3.1)

SYNTHESIS OF THE EXTERNAL DRIVERS

\begin{tabular}{|c|c|c|c|c|c|}
\hline Drivers & Indicators & Case 1 & Case 2 & Case 3 & Case 4 \\
\hline \multirow[t]{2}{*}{$\begin{array}{c}\text { Technological } \\
\text { trajectory }\end{array}$} & $\begin{array}{l}\text { Long-term } \\
\text { employment of } \\
\text { technologies that } \\
\text { are compatible } \\
\text { and/or superior to } \\
\text { those used by } \\
\text { competitors. }\end{array}$ & $\begin{array}{l}\text { Technological } \\
\text { evolution after } \\
\text { the year } 2000 \text {, } \\
\text { leading to an } \\
\text { equalization with } \\
\text { competitors. }\end{array}$ & $\begin{array}{l}\text { Evolution after } \\
2010 \text { with } \\
\text { acquisition of } \\
\text { specific } \\
\text { technologies. } \\
\text { Perceives } \\
\text { superiority in } \\
\text { comparison to } \\
\text { competitors. }\end{array}$ & $\begin{array}{l}\text { After } 2012 \text {, with } \\
\text { the implantation } \\
\text { of the Soul } \\
\text { system. } \\
\text { Compatible with } \\
\text { other hospitals of } \\
\text { the same size. }\end{array}$ & $\begin{array}{l}\text { No marked } \\
\text { transformations. } \\
\text { Technology is } \\
\text { superior to that of } \\
\text { most competitors. }\end{array}$ \\
\hline & $\begin{array}{l}\text { Technical abilities } \\
\text { and technology } \\
\text { management. }\end{array}$ & $\begin{array}{l}\text { It participates in a } \\
\text { hospital network } \\
\text { that is oriented } \\
\text { towards the } \\
\text { development of } \\
\text { technology and } \\
\text { abilities. }\end{array}$ & $\begin{array}{l}\text { At the point of } \\
\text { purchase, there is } \\
\text { training regarding } \\
\text { the technology } \\
\text { that will be } \\
\text { implemented. }\end{array}$ & $\begin{array}{l}\text { At the point of } \\
\text { purchase, it has } \\
\text { training regarding } \\
\text { the technology } \\
\text { that will be } \\
\text { implemented. }\end{array}$ & $\begin{array}{l}\text { It has periodical } \\
\text { training linked to } \\
\text { technology. }\end{array}$ \\
\hline \multirow{2}{*}{$\begin{array}{l}\text { Institutional } \\
\text { trajectory }\end{array}$} & $\begin{array}{l}\text { Incentives and } \\
\text { barriers imposed } \\
\text { by the public sector } \\
\text { throughout the } \\
\text { years. }\end{array}$ & $\begin{array}{l}\text { Previous } \\
\text { governments } \\
\text { supported the } \\
\text { hospital's } \\
\text { development. }\end{array}$ & $\begin{array}{l}\text { Promulgation of } \\
\text { the } 1988 \text { Federal } \\
\text { Constitution. }\end{array}$ & $\begin{array}{l}\text { After the } \\
\text { implantation of } \\
\text { the state } \\
\text { contracts model in } \\
2007 \text {. }\end{array}$ & $\begin{array}{l}\text { Conceived as a } \\
\text { model for Brazilian } \\
\text { Public Health } \\
\text { System hospitals. }\end{array}$ \\
\hline & $\begin{array}{l}\text { Societal taboos, } \\
\text { punishments, } \\
\text { customs, traditions } \\
\text { and codes of } \\
\text { conduct. }\end{array}$ & $\begin{array}{l}\text { Population } \\
\text { unaware of the } \\
\text { health system. }\end{array}$ & $\begin{array}{l}\text { The State adapts } \\
\text { the services in } \\
\text { this aspect. }\end{array}$ & $\begin{array}{l}\text { Regional events } \\
\text { are taken into } \\
\text { consideration, as } \\
\text { well as cases from } \\
\text { rural activities. }\end{array}$ & $\begin{array}{l}\text { Activities to } \\
\text { inform society } \\
\text { about risk } \\
\text { classification. }\end{array}$ \\
\hline Competitors & $\begin{array}{l}\text { The firm has } \\
\text { competition in its } \\
\text { partner network, } \\
\text { which facilitates } \\
\text { the sharing of } \\
\text { experiences. }\end{array}$ & $\begin{array}{l}\text { It shares } \\
\text { experiences } \\
\text { through a network } \\
\text { of partners. }\end{array}$ & $\begin{array}{l}\text { It shares } \\
\text { experience } \\
\text { through the } \\
\text { Federation of } \\
\text { Santa Casa } \\
\text { Hospitals, and } \\
\text { Beneficent, } \\
\text { Religious and } \\
\text { Philanthropic } \\
\text { Hospitals of Rio } \\
\text { Grande do Sul and } \\
\text { visits other } \\
\text { hospitals. }\end{array}$ & $\begin{array}{l}\text { It conducts and } \\
\text { receives visits } \\
\text { with the intention } \\
\text { of exchanging } \\
\text { experiences with } \\
\text { other companies. }\end{array}$ & $\begin{array}{l}\text { Participation in } \\
\text { forums and } \\
\text { partnerships with } \\
\text { other hospitals. }\end{array}$ \\
\hline
\end{tabular}




\section{(Figure 4.3.1 (conclusion))}

SYNTHESIS OF THE EXTERNAL DRIVERS

\begin{tabular}{|c|c|c|c|c|c|}
\hline Drivers & Indicators & Case 1 & Case 2 & Case 3 & Case 4 \\
\hline Competitors & $\begin{array}{l}\text { The company } \\
\text { systematically } \\
\text { compares products } \\
\text { (services) and } \\
\text { processes with } \\
\text { those of its } \\
\text { competitors. }\end{array}$ & $\begin{array}{l}\text { It does not notice } \\
\text { competition. } \\
\text { However, it } \\
\text { exchanges } \\
\text { information with } \\
\text { other partners } \\
\text { through social } \\
\text { networks. }\end{array}$ & $\begin{array}{l}\text { It participates in } \\
\text { the Regional } \\
\text { Development } \\
\text { Council of Rio } \\
\text { Grande do Sul. } \\
\text { Exchanges } \\
\text { information at } \\
\text { these encounters. }\end{array}$ & $\begin{array}{l}\text { Participates in the } \\
\text { Federation of the } \\
\text { Santas Casas, } \\
\text { where they } \\
\text { exchange } \\
\text { information with } \\
\text { other associates. }\end{array}$ & $\begin{array}{l}\text { Benchmarking at } \\
\text { the syndicate and } \\
\text { other institutions. }\end{array}$ \\
\hline & $\begin{array}{l}\text { The company } \\
\text { possesses a } \\
\text { thorough } \\
\text { knowledge of } \\
\text { consumers' needs. }\end{array}$ & $\begin{array}{l}\text { Mostly, it } \\
\text { conducts socio- } \\
\text { economic surveys. }\end{array}$ & $\begin{array}{l}\text { Satisfaction } \\
\text { surveys, periodic } \\
\text { patient visits and } \\
\text { social service. }\end{array}$ & $\begin{array}{l}\text { Satisfaction } \\
\text { surveys. }\end{array}$ & $\begin{array}{l}\text { Satisfaction } \\
\text { surveys, forms for } \\
\text { criticism, customer } \\
\text { service center and } \\
\text { forums. }\end{array}$ \\
\hline Consumers & $\begin{array}{l}\text { The firm defines } \\
\text { the consumer role } \\
\text { and develops } \\
\text { methods to } \\
\text { stimulate them to } \\
\text { participate in the } \\
\text { service provision } \\
\text { process. }\end{array}$ & $\begin{array}{l}\text { It attempts to } \\
\text { raise patient } \\
\text { awareness of } \\
\text { their role in the } \\
\text { process through } \\
\text { security services. }\end{array}$ & $\begin{array}{l}\text { Specific training } \\
\text { to seek treatment } \\
\text { humanization and } \\
\text { patient } \\
\text { engagement in } \\
\text { processes. }\end{array}$ & $\begin{array}{l}\text { Specific work is } \\
\text { intended to } \\
\text { integrate patients } \\
\text { and potential } \\
\text { patients. }\end{array}$ & $\begin{array}{l}\text { It uses consumer } \\
\text { satisfaction tools. }\end{array}$ \\
\hline \multirow[b]{2}{*}{ Suppliers } & $\begin{array}{l}\text { The company } \\
\text { maintains a good } \\
\text { relationship with } \\
\text { suppliers (mutual } \\
\text { benefit). }\end{array}$ & $\begin{array}{l}\text { It maintains a high } \\
\text { level of rotation, } \\
\text { focusing on prices } \\
\text { when making } \\
\text { purchases. }\end{array}$ & $\begin{array}{l}\text { Relations guided } \\
\text { by price and } \\
\text { quality. }\end{array}$ & $\begin{array}{l}\text { Good relationship } \\
\text { with the suppliers, } \\
\text { despite some } \\
\text { deficiencies. }\end{array}$ & $\begin{array}{l}\text { Relationships } \\
\text { guided by the } \\
\text { lowest price. }\end{array}$ \\
\hline & $\begin{array}{l}\text { The company } \\
\text { evaluates its } \\
\text { suppliers. }\end{array}$ & $\begin{array}{l}\text { Through the } \\
\text { National Supplier } \\
\text { Registration } \\
\text { System. }\end{array}$ & $\begin{array}{l}\text { Through an } \\
\text { electronic } \\
\text { platform: Bioexo. }\end{array}$ & $\begin{array}{l}\text { Through the Soul } \\
\text { platform. }\end{array}$ & $\begin{array}{l}\text { There is a specific } \\
\text { type of } \\
\text { evaluation. } \\
\text { However, no } \\
\text { details were } \\
\text { provided. }\end{array}$ \\
\hline
\end{tabular}

Source: Elaborated by the authors.

\subsection{Performance}

Finally, it is necessary to examine financial performance through the sales variation (Chiesa, Coughlan, \& Voss, 1996; Morgan et al., 2009) and profits variation indicators (Calantone et al., 2012), as well as non-financial performance based on the variation in new consumer acquisition (Kaplan \& Norton, 1996). The hospitals had different sales variations, with an increase 
in sales of $30 \%$ (case 1), $9 \%$ (case 2), $100 \%$ (case 3), and $-5 \%$ (case 4 ). Despite having positive sales variations, however, the hospitals were not profitable, which may indicate a lack of innovation. As for non-financial performance, the variation in the acquisition of new consumers fluctuated; that is, case 1 had a variation ranging from 15 to 18 thousand consumers per year, while case 2 did not have data for this indicator and case 3 is operating at its maximum capacity and is not recording this variable. Figure 4.4.1 summarizes their performance based on these indicators.

\begin{tabular}{|c|c|c|c|c|c|}
\hline & & ERFORMAN & CE SUMMARY & & \\
\hline Drivers & Indicators & Case 1 & Case 2 & Case 3 & Case 4 \\
\hline \multirow{3}{*}{ Performance } & Sales variation & $\begin{array}{l}\text { Base year } \\
\text { 2014: 30\% } \\
\text { more }\end{array}$ & $\begin{array}{l}\text { Base year } 2014: \\
9 \% \text { more }\end{array}$ & $\begin{array}{l}\text { Base year } \\
\text { 2012: 100\% } \\
\text { more }\end{array}$ & $\begin{array}{l}\text { Base year } \\
\text { 2017: 5\% less }\end{array}$ \\
\hline & Profits variation & Not profitable & Not profitable & Not profitable & Not profitable \\
\hline & $\begin{array}{l}\text { Variation in the } \\
\text { acquisition of } \\
\text { new consumers }\end{array}$ & $\begin{array}{l}\text { From } 15 \text { to } 18 \\
\text { thousand per } \\
\text { year }\end{array}$ & Not measured & Not measured & Not measured \\
\hline
\end{tabular}

Source: Elaborated by the authors.

In general, the performance driver shows the cases with positive sales variations, although none managed to be lucrative; that is, their revenues in the analyzed year were only enough to cover their expenses. In fact, in the third indicator, "variation in the acquisition of new consumers", only case 1 measures this variable.

\section{FINAL CONSIDERATIONS}

This study proposed a theoretical model to evaluate service innovation. This model consisted of nine drivers, which guide the firm towards innovation. They are organizational culture, strategies, employees, research and development, technological trajectory, institutional trajectory, competitors, consumers, and suppliers. It is important to mention that the content of the drivers may vary depending on the firm, and these variations resulted in the firm's innovation pathways. 
The model was useful to describe service innovation because the results allowed for the identification of whether a firm innovates or not, which shows that it can be replicated. This scenario is called analytical generalization and provides the model with the ability to explain innovation in service companies (Yin, 2005). The model, thus, allowed for the conclusion that the hospitals in question have difficulties innovating, because they possess only a partial concept of innovation and do not have a strategic program, generally speaking, which are essential factors, according to the drivers (Bessant \& Tidd, 2009; Toivonen \& Tuominen, 2009).

The hospitals emphasize technology to the detriment of other variables that could generate other types of innovation because, as is known, service innovation is a multidimensional phenomenon (Martin et al., 2016). This perception of innovation as the adoption of technology leads to strategies that are specifically skewed towards technology and not systemic strategies that aim to attain innovation within the multiple existing dimensions. Furthermore, in the institutional trajectory driver, we discovered that there is a strong dependency on public policies, which, in turn, restricts hospital management.

Since innovation basically consists of obtaining superior performance through the proposition of value (Schumpeter, 1997; Damanpour, 1991; Skålen et al., 2015), while using the proposed theoretical model, it was possible to see that the hospitals do not innovate because, despite obtaining positive sales variations, they were not profitable. It was possible to see that service provision exists in its basic conception supported by information technology, which the hospitals managed to acquire with much effort. Therefore, hospitals analyzed work in the technological paradigm (Barras, 1986). They depend on the state and do not possess a strategic program for innovation.

Considering the results obtained by this work, there may be some advantages in using this model to analyze service innovation. The model offers not only a systemic view of which drivers can lead a service firm to innovate, but it also seeks, in the same way, to include variables stemming from both the outside and the inside environments, which are constantly changing. The advantages of this model may reflect upon firm management since this encompassing vision permits the implementation of managerial practices that attempt to better equate each variable according to its indicators. It also offers the understanding that it is not enough to merely consider another driver. It is necessary to search for a systemic management of the drivers, which is a sine qua non condition for service innovation.

Finally, the study has a limitation based on the type of hospital that was analyzed. The hospitals that were included were public hospitals, which may cause some variation in the drivers, considering their dependence on 
public policies and their reduced autonomy for investment. This limitation prompts a suggestion for future research, that is to say, it is necessary to broaden the scope, including private hospitals. We also suggest that this model be applied quantitatively.

\section{DRIVERS DA INOVAÇÃO EM SERVIÇOS: PROPOSIÇÃO DE UM MODELO TEÓRICO}

\section{RESUMO}

Objetivo: Propor um modelo teórico suportado em nove drivers da inovação em serviços (cultura organizacional, estratégias, pesquisa e desenvolvimento, capital humano, competidores, clientes, fornecedores, trajetória tecnológica, trajetória institucional) para compreender o fenômeno. Originalidade/valor: Dado o seu recente protagonismo e pelo enfoque manufatureiro inicialmente recebido, a inovação em serviços ainda carece de modelos que busquem compreender o fenômeno dentro de um framework abrangente e particular. A originalidade do trabalho surge dessa problemática.

Design/metodologia/abordagem: O método consiste em um estudo de casos múltiplos. Para sua execução, utilizaram-se entrevistas semiestruturadas com gestores estratégicos de hospitais, além de pesquisa documental com a análise de balanços contábeis, organogramas, entre outros. Para a análise dos resultados, utilizou-se a compreensão dos casos em uma perspectiva sistêmica, por meio da síntese de casos cruzados, permitindo a comparação de casos em uma mesma estrutura.

Resultados: O modelo permitiu identificar que os hospitais em análise apresentam dificuldades para inovar, dadas algumas características levantadas a partir dos drivers propostos por este trabalho. Mais especificamente, os hospitais possuem conceito unidimensional e defasado da inovação, isto é, consideram a inovação em serviços como a adoção das tecnologias oriundas da indústria, tal qual se considerava com Barras (1986), além de inexistirem programas estratégicos de inovação.

\section{PALAVRAS-CHAVE}

Inovação. Serviços. Drivers. Modelo teórico. Hospitais. 


\section{REFERENCES}

Abouzeedan, A., Klofsten, M., \& Hedner, T. (2013). Internetization management as a facilitator for managing innovation in high-technology smaller firms. Global Business Review, 14(1), 121-136. doi:10.1177/0972150912 466462

Barras, R. (1986). Towards a theory of innovation in services. Research Policy, 15(4), 161-173. doi:10.1016/0048-7333(86)90012-0

Bell, D. (1973). The corning of post-industrial society. London: Heinemann.

Berger, P. L., \& Luckmann, T. (1978). Construção social da realidade. Petrópolis: Vozes.

Bessant, J., \& Tidd, J. (2009). Inovação e empreendedorismo: Administração. Porto Alegre: Bookman.

Bharadwaj, A. S. (2000). A resource-based perspective on information technology capability and firm performance: An empirical investigation. MIS Quarterly, 24(1), 169-196. doi.org/10.2307/3250983

Calantone, R. J., Cavusgil, S. T., \& Zhao, Y. (2002). Learning orientation, firm innovation capability, and firm performance. Industrial Marketing Management, 31 (6), 515-524. doi:10.1016/S0019-8501(01)00203-6

Camisón, C., \& Monfort-Mir, V. M. (2012). Measuring innovation in tourism from the Schumpeterian and the dynamic-capabilities perspectives. Tourism Management, 33(4), 776-789. doi:10.1016/j.tourman.2011.08.012

Chen, J. S., Tsou, H. T., \& Huang, A. Y. H. (2009). Service delivery innovation antecedents and impact on firm performance. Journal of Service Research, 12(1), 36-55. doi:10.1177/1094670509338619

Chiesa, V., Coughlan, P., \& Voss, C. A. (1996). Development of a technical innovation audit. Journal of Product Innovation Management, 13(2), 105-136. doi:10.1111/1540-5885.1320105

Claver, E., Llopis, J., Garcia, D., \& Molina, H. (1998). Organizational culture for innovation and new technological behavior. Journal of High Technology Management Research, 9(1), 55-69. doi:10.1016/1047-8310(88)90005-3

Community Innovation Survey (2012). Community innovation survey 20082010. Dublin: Stationery Office. 
Damanpour, F. (1991). Organizational innovation: A meta-analysis of effects of determinants and moderators. Academy of Management Journal, 34(3), 555-590. doi:10.5465/256406

Daniel, V. M., Lima, M. P., \& Ferrari Dambros, Â. M. (2017). Innovation capabilities in services: A multi-cases approach. Academia Revista Latinoamericana de Administración, 30(4), 490-507. doi:10.1108/ARLA-06-20160161

Dosi, G. (1982). Technological paradigms and technological trajectories: A suggested interpretation of the determinants and directions of technical change. Research Policy, 11 (3), 147-162. doi:10.1016/0048-7333(82)90016-6

Durst, S., Mention, A. L., \& Poutanen, P. (2015). Service innovation and its impact: What do we know about? Investigaciones Europeas de Dirección y Economía de la Empresa, 21 (2), 65-72. doi:10.1016/j.iedee.2014.07.003

Gallouj, F. (2002). Innovation in the service economy: The new wealth of nations. Cheltenham: Edward Elgar.

Gallouj, F., \& Weinstein, O. (1997). Innovation in services. Research Policy, 26(4-5), 537-556. doi:10.1016/S0048-7333(97)00030-9

Hauknes, J. (1998). Services in innovation-innovation in services. STEP Report R13/1998. Oslo: STEP Group.

Hsueh, J.-T., Lin, N.-P., \& Li, H.-C. (2010). The effects of network embeddedness on service innovation performance. The Service Industries Journal, 30(10), 1723-1736. doi:10.1080/02642060903100398

Kaplan, R. S., \& Norton, D. P. (1996). The balanced scorecard: Translating strategy into action. London: Harvard Business Press.

Kindström, D., Kowalkowski, C., \& Sandberg, E. (2013). Enabling service innovation: A dynamic capabilities approach. Journal of Business Research, 66(8), 1063-1073. doi:10.1016/j.jbusres.2012.03.003

Larivière, B., Bowen, D., Andreassen, T. W., Kunz, W., Sirianni, N. J., Voss, C., Wünderlich, N. V., \& De Keyser, A. (2017). Service encounter 2.0: An investigation into the roles of technology, employees and customers. Journal of Business Research, 79, 238-246. doi:10.1016/j.jbusres.2017.03.008

Leiponen, A. (2006). Organization of knowledge exchange: An empirical study of knowledge-intensive business service relationships. Economics of Innovation and New Technology, 15(4-5), 443-464. doi:10.1080/10438590 500512976 
Madrid-Guijarro, A., Garcia, D., \& Auken, H. (2009). Barriers to innovation among Spanish manufacturing SMEs. Journal of Small Business Management, 47(4), 465-488. doi:10.1111/j.1540-627X.2009.00279.x

Malhotra, N. (2012). Pesquisa de marketing: Uma orientação aplicada (6a ed.). Porto Alegre: Bookman.

Marcus, A. A., \& Geffen, D. (1998). The dialectics of competency acquisition: Pollution prevention in eclectic generation. Strategic Management Journal, 20, 1133-1156. doi:10.1002/(SICI) 1097-0266(1998120) 19:12<1145:: AID-SMJ6>3.0.CO;2-B

Martin, D., Gustafsson, A., \& Choi, S. (2016). Service innovation, renewal, and adoption/rejection in dynamic global contexts. Journal of Business Research, 69(7), 2387-2400. doi:10.1016/j.jbusres.2016.01.008

McLean, L. D. (2005). Organizational culture's influence on creativity and innovation: A review of the literature and implications for human resource development. Advances in Developing Human Resources, 7(2), 226-246. doi: $10.1177 / 1523422305274528$

Miron, E., Erez, M., \& Naveh, E. (2004). Do personal characteristics and cultural values that promote innovation, quality, and efficiency compete or complement each other? Journal of Organizational Behavior, 25, 175-199. doi:10.1002/job.237

Morgan, N. A., Vorhies, D. W., \& Mason, C. H. (2009). Market orientation, marketing capabilities, and firm performance. Strategic Management Journal, 30(8), 909-920. doi.org/10.1002/smj.764

Naranjo-Gil, D. (2009). The influence of environmental and organizational factors on innovation adoptions: Consequences for performance in public sector organizations. Technovation, 29(12), 810-818. doi:10.1016/j. technovation.2009.07.003

Nelson, R., \& Winter, S. (1982). An evolutionary theory of technical change. Cambridge: Beknap Harvard.

Ojasalo, J., \& Ojasalo, K. (2018). Lean service innovation. Service Science, 10(1), 25-39. doi:10.1287/serv.2017.0194

Ordanini, A., \& Parasuraman, A. (2011). Service innovation viewed through a service-dominant logic lens: A conceptual framework and empirical analysis. Journal of Service Research, 14 (1), 3-23. doi:10.1177/1094670510385332

Ostrom, A., Bitner, M., Brown, S., Burkhard, K., Goul, M., Smith-Daniels, V., ... \& Rabinovich, E. (2010). Moving forward and making a difference: Research priorities for the science of service. Journal of Service Research, 13(1), 4-36. doi:10.1177/1094670509357611 
Pilat, D. (2000). No longer services as usual. The OECD Observer, 223, 52.

Pinto, G. L., Dell'Era, C., Verganti, R., \& Bellini, E. (2017). Innovation strategies in retail services: Solutions, experiences and meanings. European Journal of Innovation Management, 20(2), 190-209. doi:10.1108/EJIM-06-20150049

Pires, C. P., Sarkar, S., \& Carvalho, L. (2008). Innovation in services - How different from manufacturing? The Service Industries Journal, 28(10), 13391356. doi:10.1080/02642060802317812

Prajogo, D., \& McDermott, C. M. (2014). Antecedents of service innovation in SMEs: Comparing the effects of external and internal factors. Journal of Small Business Management, 52(3), 521-540. doi:10.1111/jsbm.12047

Radaelli, G., Currie, G., Frattini, F., \& Lettieri, E. (2017). The role of managers in enacting two step institutional work for radical innovation in professional organizations. Journal of Product Innovation Management, 34(4), 450-470. doi:10.1111/jpim.12385

Salunke, S., Weerawardena, J., \& McColl-Kennedy, J. R. (2019). The central role of knowledge integration capability in service innovation-based competitive strategy. Industrial Marketing Management, 76, 144-156. doi:10. 1016/j.indmarman.2018.07.004

Schumpeter, J. (1911/1997). A teoria do desenvolvimento econômico. (Coleção Os economistas). São Paulo: Nova Cultura.

Shattow, M. (1996). Out of the blue. Electric Perspectives, 21 (3), 44-54.

Skålén, P., Gummerus, J., Khoskull, C., \& Magnusson, P. (2015). Exploring value propositions and service innovation: A service-dominant logic study. Journal of the Academy of Marketing Science, 43(2), 137-158. doi:10.1016/j. indmarman.2018.07.004

Smith, A. (1983). A riqueza das nações. São Paulo: Abril Cultural.

Sundbo, J. (2006, June 15-17). Customer-based innovation of e-knowledge services: The importance of after-innovation. ASEAT Conference, Manchester.

Taghizadeh, S. K., Rahman, S. A., \& Hossain, M. M. (2018). Knowledge from customer, for customer or about customer: Which triggers innovation capability the most? Journal of Knowledge Management, 22(1), 162-182. doi:10.1108/JKM-12-2016-0548

Thanasopon, B., Papadopoulos, T., \& Vidgen, R. (2016). The role of openness in the fuzzy front-end of service innovation. Technovation, 47, 32-46. doi:10.1016/j.technovation.2015.11.007 
Toivonen, M., \& Tuominen, T. (2009). Emergence of innovations in services. The Service Industries Journal, 29(7), 887-902. doi:10.1080/02642060 902749492

Winter, S., \& Lasch, R. (2016). Recommendations for supplier innovation evaluation from literature and practice. International Journal of Operations $\mathcal{E}$ Production Management, 36(6), 643-664. doi:10.1108/IJOPM-07-2014-0341

Witell, L., Gebauer, H., Jaakkola, E., Hammedi, W., Patricio, L., \& Perks, H. (2017). A bricolage perspective on service innovation. Journal of Business Research, 79, 290-298. doi:10.1016/j.jbusres.2017.03.021

Yam, R. C. M., Guan, J. C., Pun, K. F., \& Tang, E. P. Y. (2004). An audit of technological innovation capabilities in Chinese firms: Some empirical findings in Beijing, China. Research Policy, 33(8), 1123-1140. doi:10.1016/j. respol.2004.05.004

Yin, R. K. (2005). Estudo de caso: Planejamento e métodos. Porto Alegre: Bookman.

\section{$\int$ AUTHOR NOTES}

Ricardo M. Leo, master from the Postgraduate Program in Administration, Federal University of Rio Grande (Furg); Jorge Tello-Gamarra, Ph.D. from the Postgraduate Program in Administration, Federal University of Rio Grande do Sul (UFRGS).

Ricardo M. Leo is now a doctorate student and researcher at the Innovation Research Center (Nitec) of Federal University of Rio Grande do Sul (UFRGS); Jorge Tello-Gamarra is now an adjunct professor at the School of Food and Chemistry of Federal University of Rio Grande (Furg).

Correspondence concerning this article should be addressed to Ricardo M. Leo, Rua Washington Luiz, 855, Centro Histórico, Porto Alegre, Rio Grande do Sul, Brazil, CEP 90010-460.

E-mail: ricardomachado_3@hotmail.com

EDITORIAL BOARD

Editor-in-chief

Gilberto Perez

Associated Editor

Gisela Demo

Technical Support

Vitória Batista Santos Silva

\section{EDITORIAL PRODUCTION}

Publishing Coordination

Jéssica Dametta

Layout Designer

Editorial Intern

Paula Di Sessa Vavlis

Language Editor

Daniel de Almeida Leão
Emap

Graphic Designer

Libro 